\title{
STRATEGI PENGEMBANGAN PRODUK DAN PELAYANAN UNTUK MENINGKATKAN NIAT BERKUNJUNG WISATAWAN KE MUSEUM NASIONAL DKI JAKARTA
}

\author{
Firman Syah \\ Program Studi MICE, Politeknik Negeri Jakarta \\ Email: firman_tegal@yahoo.com
}

\begin{abstract}
Strategy of development directing tourism growth toward local needs, interests, and limits can greatly enhance tourism value to the community and help create a sustainable industry. The longterm sustainability of tourism rests on the ability of community leaders and tourism professionals to maximize its benefits and minimize its costs.

This study uses a qualitative kind of explanation to identify prospective business National Museum. The results show the diversity of products is a collection that can be shown to tourists. Services for tourists as security every corner of the room, adequate facilities, and service pre-wedding. However, the parking lot is cramped and the toilets and prayer is still minimal then it must be upgraded to meet the needs of travelers.

The development strategy implemented through creativity, like dioramas that make it easier for tourists information and voice record as a substitute for tourist guides. If the development of damning it can apply CSR to companies at home and abroad for the betterment of historic culture.
\end{abstract}

Key Word: Tourism, Development Strategy, Product, Service, and Museum Nasional

\begin{abstract}
Abstrak
Strategi pengembangan destinasi wisata pada dasarnya mengarahkan pertumbuhan pariwisata terhadap kebutuhan lokal, kepentingan, dan batas dapat meningkatkan nilai pariwisata kepada masyarakat dan membantu menciptakan industri yang berkelanjutan. Keberlanjutan jangka panjang dari pariwisata bertumpu pada kemampuan tokoh masyarakat dan profesional pariwisata untuk memaksimalkan manfaat dan meminimalkan biaya.

Penelitian ini menggunakan kualitatif dengan jenis eksplanasi untuk mengidentifikasi prospektif bisnis Museum Nasional. Hasil menunjukkan keragaman produk merupakan salah satu kekayaan koleksi yang dapat diperlihatkan kepada wisatawan. Pelayanan yang diberikan kepada wisatawan seperti keamanan di setiap sudut ruangan, fasilitas yang memadai, dan berbagai pilihan produk seperti pre-wedding. Namun, lahan parkir masih tergolong sempit serta toilet dan mushola yang terbilang minim harus ditingkatkan untuk memenuhi harapan wisatawan.

Strategi pengembangan dapat dilaksanakan melalui kreativitas, misalnya pembuatan diorama sehingga mudah dimengerti wisatawan dan pengadaan voice record sebagai pengganti pemandu bagi wisatawan asing. Jika pengembangan ini dirasa memberatkan maka Museum Nasional dapat mengajukan anggaran melalui CSR ke perusahaan di dalam maupun luar negeri demi kemajuan kebudayaan yang bernilai sejarah.
\end{abstract}

Kata Kunci: Pariwisata, Strategi Pengembangan, Produk, Pelayanan, dan Museum Nasional

\section{PENDAHULUAN}

Saat ini sektor kepariwisataan menjadi salah satu industri yang berkembang pesat. Hampir semua negara mengembangkan potensi pariwisata dari berbagai aspek. Dalam karyanya, Albrecht (2017) menjelaskan implementasi dari tujuan strategi pariwisata di tingkat nasional adalah untuk jangka panjang. Langkah ini 
dengan mendeskripsikan teori implementasi ilmu politik, implementasi pada strategi pariwisata sebelumnya, dan memeriksa jaringan pemangku kepentingan dari pelaksanaan strategi pariwisata Selandia Baru periode 2015. Hasil wawancara dengan metode kualitatif ini menawarkan penjelasan untuk tantangan implementasi yang dihadapi termasuk dilema terkait dengan jenis dan jumlah pemangku kepentingan yang terlibat dalam pelaksanaan strategi, tujuan strategi, dan masalah sistemik yang melekat dalam kolaborasi sektor publikswasta.

Untuk di DKI Jakarta ada salah satu museum yang menyimpan benda-benda bersifat budaya, yaitu Museum Nasional. Nama lain dari Museum Gajah ini mengoleksi benda-benda bersejarah yang dipergunakan manusia di masa lalu dalam melangsungkan hidup. Banyak kegiatan yang dilakukan untuk berburu, bercocok tanam, membuat tempat tinggal, dan lain sebagainya. Di sisi lain, alat tersebut dipergunakan dalam berperang membela diri dan memertahankan hidup. Semua itu dilakukan sebagai mata rantai kehidupan manusia di masa lalu, sehingga muncul perubahan zaman dan membuat siklus kehidupan manusia berubah. Tak heran Museum Nasional merupakan sebuah lembaga studi warisan budaya dan pusat informasi edukatif kultural dan rekreatif. Museum ini mempunyai kewajiban menyelamatkan dan melestarikan benda warisan budaya bangsa Indonesia. Hingga saat ini koleksi yang dikelola berjumlah 141.899 benda, terdiri atas 7 jenis koleksi yaitu prasejarah, arkeologi, keramik, numismatik-heraldik, sejarah, etnografi dan geografi (Museum Nasional, 2013).

Museum Nasional menyimpan kekayaan budaya masyarakat dari masa lalu. Ini sebagai tongkat kesinambungan budaya di masa kini. Tanpa adanya masa lalu, maka tak ada masa kini. Sebagai salah satu pengetahuan kebudayaan, Museum Nasional semestinya memiliki kondisi ideal dari sebuah museum. Dimana, para pengunjung dapat menyerap ilmu-ilmu yang terdapat di dalam museum. Dengan dibantu oleh seorang pemandu, pengunjung diharapkan dapat mencerna dan mengetahui sejarah yang terkandung dalam benda-benda koleksi Museum Nasional. Pada kenyataannya, pengembangan produk dan pelayanan yang diberikan oleh Museum Nasional masih minim. Sebagian besar pengunjung dengan status pelajar ini pada akhirnya sekedar senang untuk melihat koleksi saja atau menuntaskan kewajiban dalam tugas dari pihak sekolah. Diperlukan suatu pemecahan masalah yang tepat dalam pengembangan produk dan pelayanan yang diberikan oleh Museum Nasional. Tujuannya, supaya informasi yang mengandung pesan sejarah dari Museum Nasional ini dapat tersampaikan dengan baik dan menyenangkan wisatawan.

Hasil kajian Ylli (2016) seputar Penelitian ini menguji pola pengembangan pariwisata Albania dan efek industri dalam pembangunan ekonomi negara. Menurutnya, pariwisata merupakan industri yang sangat diperlukan di negaranegara berkembang seperti Albania. Jika berkembang melalui strategi yang tepat dengan pemerintah dan dukungan kelembagaan lain dapat berkontribusi pada pembangunan negara. Meskipun sifat dan karakteristik dari tantangan beragam serta rumit, negara harus mulai menangani isuisu yang pada akhirnya memungkinkan pertumbuhan organik pariwisata. Yaitu pemasaran, pengembangan produk, investasi di zona prioritas, investasi dalam budaya, Sumber Daya Manusia (SDM), infrastruktur, iklim usaha, dan manajemen informasi.

Kesimpulan yang diambil dari temuan tersebut adalah tugas berat untuk mengembangkan produk dan pelayanan di destinasi wisata tak terkecuali Museum Nasional ada di tangan SDM. Keprofesionalan SDM dalam melaksanakan tugas membuat bisnis pariwisata berjalan lancar dan membuahkan keuntungan. Untuk itu, Museum Nasional dituntut serius dalam 
memertahankan eksistensi destinasi wisata melalui pengembangan produk dan pelayanan sehingga dapat meningkatkan niat berkunjung wisatawan. Maka, berbagai pengujian perlu dilakukan guna memastikan respon positif pengunjung yang menguntungkan dan potensial (Holloway, Humphreys, and Davidson, 2009: 71).

Sebagai destinasi wisata, Museum Nasional menyediakan beragam kebudayaan daerah yang ditata berdasarkan jenisnya. Baik berdasarkan keilmuan, bahan, maupun kedaerahan, dengan subtema manusia dan lingkungan, ilmu pengetahuan, teknologi dan ekonomi, organisasi sosial dan pola pemukiman, serta khasanah dan keramik. Upaya menyelamatkan budaya bangsa Indonesia sepatutnya dilakukan dengan mengampanyekan cinta budaya lokal sebagai aset bangsa. Beragam kegiatan dan cara untuk melestarikan sekaligus memerkenalkan kepada masyarakat luas, terutama yang belum mengetahui. Baik pada tingkat nasional maupun internasional.

Fenomena pengembangan produk dan pelayanan atas Museum Nasional yang mengandung nilai-nilai sejarah dan kebudayaan sangat menarik untuk dikaji. Untuk itu, peran Museum Nasional sebagai Badan Layanan Umum (BLU) dengan tujuan sebagai pusat informasi tentang warisan budaya dan seni Indonesia harus dikedepankan. Sebab, BLU merupakan instansi di lingkungan pemerintah yang dibentuk untuk memberikan pelayanan kepada masyarakat berupa penyediaan barang dan/atau jasa yang dijual tanpa mengutamakan keuntungan. Karena, pada dasarnya keberadaan BLU adalah memajukan kesejahteraan umum dan mencerdaskan kehidupan bangsa (PP No. 23 Tahun 2005).

Dari sini muncul beberapa rumusan masalah, yaitu:

1. Bagaimana produk dan pelayanan yang sudah diberikan oleh Museum Nasional?
2. Bagaimana strategi pengembangan yang dapat dilaksanakan oleh Museum Nasional?

\section{Kajian Pustaka \\ Kepariwisataan}

Dalam Undang-Undang Nomor 10 Tahun 2009 Tentang Kepariwisataan, Pasal 1 (4) kepariwisataan merupakan keseluruhan kegiatan yang terkait dengan pariwisata dan bersifat multidimensi serta multidisiplin yang muncul sebagai wujud kebutuhan setiap orang dan negara serta interaksi antara wisatawan dan masyarakat setempat, sesama wisatawan, Pemerintah, Pemerintah Daerah, dan pengusaha. Sifat yang multidimensi, pariwisata masuk ke ranah kehidupan dengan ciri khas sesuai problematika yang ada baik sejarah, ekonomi, pendidikan, daerah, sosial, politik, idiologi, biologis, dan seterusnya.

Adapun seluruh kegiatan bersifat multidisiplin terletak pada pandangan yang meninjau dan menelaah suatu persoalan dari berbagai disiplin ilmu. Baik itu sosiologi, psikologi, ekonomi, politik, hukum, pendidikan, manajemen, administrasi, komunikasi, teknologi, pertanian, kehutanan, maritim, kesehatan, dan bidang ilmu yang lain. Masing-masing disiplin ilmu tersebut memiliki kajian untuk mengembangkan destinasi wisata. Jika disatukan menjadi multidisiplin ilmu untuk mengundang wisatawan. Sosiologi dapat melakukan kajian terhadap ketimpangan yang terjadi di tengah-tengah masyarakat. Dengan harapan dapat menemukan formula efektif sehingga tidak ada lagi pengangguran dan masyarakat berkategori tidak mampu melalui pemberian lapangan kerja di lingkungan mereka sendiri karena potensi destinasi wisata yang ada.

World Tourism Organization (2008) menjelaskan pariwisata merupakan industri yang menangani jasa seperti jasa transportasi; jasa keramahan tempat tinggal, makanan, minuman; jasa yang bersangkutan lain yaitu perbankan, asuransi, keamanan dan lain-lain dan juga 
menawarkan tempat istirahat, budaya, pelarian, petualangan, serta pengalaman baru dan berbeda lain. Adapun unsur utama produk terletak pada nilai-nilai yang sudah melekat karena keunikan tradisi lokal. Daya tarik produk destinasi wisata dengan basis kearifan lokal atau biasa disebut ekowisata memiliki daya tarik bagi wisatawan. Hal ini juga yang terjadi di Museum Nasional. Walau atraksi produk lebih menampilkan latar belakang kehidupan manusia di Indonesia, namun kegiatan yang ada juga dikemas ragam fasilitas pendukung. Antara lain cara membatik, cara merajuk kain, atau seni melukis secara tradisional.

\section{Produk dan Pelayanan}

Penting bagi destinasi wisata untuk membedakan kebutuhan, keinginan, dan permintaan yang datang dari pengunjung. Kebutuhan manusia adalah ketidakberadaan beberapa kebutuhan dasar yang ada di destinasi wisata. Manusia membutuhkan makanan, tempat berlindung, keamanan, hak milik, dan harga diri. Kebutuhan tersebut tidak dapat diciptakan oleh masyarakat atau pemasar. Mereka merupakan hakikat biologis dan kondisi manusia (Kotler \& Keller, 2009). Sementara keinginan manusia hampir tidak terbatas, namun yang membatasi adalah diri manusia tersebut. Dan permintaan manusia senantiasa muncul untuk dapat terpuaskan sepenuhnya, baik yang menjadi kebutuhan maupun sekedar keinginan.

Dibutuhkan pengelolaan pariwisata yang efektif dan efisien supaya destinasi wisata dapat lebih profesional dalam memberikan pelayanan kepada pengunjung. Salah satunya produk dan pelayanan. Produk adalah segala sesuatu yang dapat ditawarkan ke pasar untuk mendapatkan perhatian, dibeli, dimiliki, digunakan, atau dikonsumsi yang dapat memuaskan keinginan atau kebutuhan pemakainya (Kotler dan Armstrong, 2012). Produk ini menjadi sesuatu yang bernilai untuk menghasilkan keuntungan yang maksimal. Produk yang dihasilkan sejatinya ideal dengan keinginan pasar.

Adapun pelayanan seperti yang diberikan oleh Museum Nasional semestinya dapat memuaskan wisatawan. Biasanya, pelayanan sebagai hasil dan tindakan untuk mewujudkan perubahan yang diinginkan dalam diri atau atas nama penerima jasa tersebut. Sehingga, melalui pelayanan itu muncul nilai bagi pelanggan untuk menjalin hubungan dengan menciptakan nilai-nilai pelanggan. Pelayanan adalah tindakan atau kegiatan yang dapat ditawarkan oleh satu pihak kepada pihak lain pada dasarnya tidak berwujud dan tidak mengakibatkan kepemilikan apapun. (Kotler \& Keller, 2009: 85).

Terdapat empat faktor yang mempengaruhi kualitas pelayanan, yaitu:

1. Menjaga dan memperhatikan. Artinya, wisatawan akan merasakan keberadaan karyawan dan sistem operasional yang ada di Museum Nasional dapat menyelesaikan masalah pengunjung.

2. Spontanitas. Dimana karyawan menunjukkan keinginan untuk menyelesaikan masalah pengunjung.

3. Penyelesaian masalah. Karyawan yang berhubungan langsung dengan pengunjung harus memiliki kemampuan untuk menjalankan tugas berdasarkan standar yang ada.

4. Perbaikan. Apabila terjadi hal-hal yang tidak diinginkan mempunyai karyawan lain yang dapat menyiapkan usaha-usaha khusus (Christian Gronroos, 2001)

\section{Strategi Pengembangan}

Strategi pengembangan destinasi wisata pada dasarnya mengarahkan pertumbuhan pariwisata terhadap kebutuhan lokal, kepentingan, dan batas dapat meningkatkan nilai pariwisata kepada masyarakat dan membantu menciptakan industri yang berkelanjutan. Dalam karyanya, Kreag (2001) menjelaskan keberlanjutan jangka panjang dari 
pariwisata bertumpu pada kemampuan tokoh masyarakat dan profesional pariwisata untuk memaksimalkan manfaat dan meminimalkan biaya. Banyak masyarakat kecil memiliki keterampilan dan sumber daya untuk pengembangan pariwisata yang sukses. Menciptakan industri pariwisata lokal bukanlah tugas yang menakutkan, tetapi membuat pariwisata benar-benar 'cocok' bagi masyarakat yang membutuhkan kerja. Menciptakan industri pariwisata yang sukses dan berkelanjutan seperti menciptakan aktivitas ekonomi yang sukses dan berkelanjutan.

Setiap kategori tersebut memiliki dampak positif dan negatif. Masyarakat dan pemimpin pariwisata harus menyeimbangkan berbagai dampak yang mungkin positif untuk meningkatkan atau negatif mempengaruhi masyarakat dan masyarakat. Pemimpin harus peka dan visioner, dan harus menghindari godaan dari komentar atas kesulitan-kesulitan tertentu dalam menciptakan pengembangan pariwisata. Pemimpin pariwisata juga harus menyeimbangkan peluang dan keprihatinan semua sektor masyarakat dengan bekerja melawan kondisi manfaat dari dampak positif dari menyakiti dampak negatif (geografis atau sosial) yang lain. Pemimpin lokal tidak harus mengharapkan pariwisata dapat menyelesaikan semua masalah masyarakat, karena pariwisata merupakan salah satu elemen dari masyarakat.

Ylli (2016) juga mengakui pola pengembangan industri pariwisata Albania misalnya akan memiliki dampak dalam pembangunan ekonomi negara. Pariwisata merupakan industri yang sangat diperlukan negara-negara berkembang dan dapat berkembang melalui strategi yang tepat antara pemerintah dan dukungan kelembagaan lain. Awalnya, pariwisata di Albania disebut sebagai bayi dari pariwisata internasional di era 1990-an setelah rezim komunis yang memerintah selama 50 tahun jatuh. Pejabat Kantor Pemerintah Albania menunjukkan perkembangan industri pariwisata internasional yang kompetitif mungkin $80 \%$ dari garis pantai yang belum tersentuh tangan manusia. Musim panas lalu jumlah pengunjung asing mencapai 900.000 yang menunjukkan pariwisata negara tersebut mengalami 'booming' dimana ada peningkatan pengunjung pariwisata sebanyak 35\% dibandingkan tahun-tahun sebelumnya, yakni 92\% berasal dari Eropa, 5\% Amerika, 2\% Asia dan $1 \%$ dari negara lain.

Maka infrastruktur terus mengalami perbaikan. Dalam 15 tahun lalu jalan raya dan layanan udara internasional diprivatisasi. Pemerintah mencoba mempromosikan dan mengembangkan industri tertentu atau sektor ekonomi untuk menghadapi tantangan dan mengatasi hambatan. Dalam kasus Albania, keseluruhan tantangan umum dan tantangan khusus sukses diturunkan langsung pada industri pariwisata berbasis alam dan budaya yang dapat dianalisis dan diteliti lebih lanjut.

Lebih lanjut Ylli menjabarkan tantangan pariwisata secara keseluruhan, yaitu harus menentukan dengan tepat posisi pariwisata di arena internasional dan sedang mencoba menentukan target segmen serta investasi yang secara spesifik untuk jangka panjang, menengah, dan pendek. Adapula koordinasi dengan pihak lain yang dibutuhkan oleh sektor pariwisata supaya mengalami kesuksesan program baik akademi ilmu pengetahuan dan universitas, lembaga internasional seperti bank dunia dan kolaborasi dengan negara tetangga.

\section{METODOLOGI PENELITIAN}

Penelitian ini menggunakan kualitatif dengan jenis eksplanasi (tingkat penjelasan) untuk mengidentifikasikan prospektif bisnis yang dilaksanakan oleh Museum Nasional. Di sini, penulis memerlukan dua jenis data untuk mendapatkan beberapa informasi, yaitu data primer yang dikumpulkan langsung 
dari sumber utama yakni Pimpinan Museum Nasional dan wisatawan yang dipilih secara acak sebagai responden utama untuk mengetahui niat berkunjung wisatawan. Selain itu terdapat data sekunder yang bersumber melalui studi pustaka. Di antaranya data internal dari Museum Nasional, data eksternal dari studi pustaka untuk memperoleh gambaran secara jelas baik dari journal international maupun buku-buku. Analisis data merupakan langkah penting untuk memperoleh temuan-temuan hasil penelitian secara ilmiah sehingga dapat diambil kesimpulan.

\section{HASIL DAN PEMBAHASAN}

Museum Nasional yang dikenal masyarakat umum seperti Jakarta sebagai Museum Gajah merupakan lokasi penyimpanan ragam koleksi kebudayaan di Indonesia. Dikenal Gedung Gajah ini karena di halaman depan museum terdapat patung gajah perunggu hadiah Raja Chulalongkorn (Rama V) dari Thailand yang pernah berkunjung ke museum tersebut pada tahun 1871. Hingga 2014 jumlah koleksi yang dikelola Museum Nasional berjumlah 141.899 benda-benda bernilai sejarah yang terdiri dari koleksi prasejarah, arkeologi, keramik, numismatik-heraldik, sejarah, etnografi, dan geografi. Termasuk menyimpan peninggalan alat-alat kebesaran, seperti mahkota dari kerajaan-kerajaan zaman dahulu di Indonesia. Eksistensi Museum Nasional diawali dengan berdirinya suatu himpunan yang bernama Bataviaasch Genootschap van Kunsten en Wetenschappen, didirikan oleh Pemerintah Belanda pada tanggal 24 April 1778.

Sebagai lembaga resmi pemerintah, Museum Nasional berada di bawah Direktorat Jenderal Sejarah dan Purbakala Kementerian Kebudayaan dan Pariwisata. Fungsi dari Museum Nasional adalah sebagai pusat informasi khasanah budaya bangsa yang bersifat edukatif pusat budaya penelitian dan studi warisan budaya bangsa, juga menyebarluaskan informasi kepada masyarakat baik melalui pameran, penerbitan buku atau brosur dan program kegiatan umum.

Komplek Museum Nasional dibangun di atas tanah seluas sekitar $26.500 \mathrm{M}^{2}$ hingga saat mempunyai dua gedung. Gedung lama (unit A). Ruang ini digunakan untuk memamerkan koleksi museum dan ruang penyimpanan koleksi (storage) berdasarkan pada jenis-jenis koleksi, baik berdasarkan keilmuan, bahan, maupun kedaerahan. Seperti ruang pameran prasejarah, ruang perunggu, ruang tekstil, ruang etnografi daerah Sumatera, dan lain-lain. Kedua gedung B (Gedung Arca) yang dibuka secara resmi pada tanggal 20 Juni 2007 oleh DR. Susilo Bambang Yudhoyono (Presiden RI). Selain digunakan untuk ruang pameran (lantai 1 sampai 4), juga digunakan untuk kantor, ruang konferensi, laboratorium, perpustakaan, dan lain-lain. Di sini tidak lagi berdasarkan jenis koleksi, melainkan mengarah kepada tema berdasarkan aspekaspek kebudayaan yang mana manusia diposisikan sebagai pelaku dalam lingkungan tempat tinggalnya. Tema pameran yang berjudul "Keanekaragaman Budaya dalam Kesatuan” ini terdiri dari beberapa subtema antara lain manusia dan lingkungan; ilmu pengetahuan; teknologi dan ekonomi; organisasi sosial dan pola pemukiman, serta khasanah dan keramik. Ada juga gedung unit $\mathrm{C}$ yang direncanakan akan dibangun untuk memerluas tata pameran yang sudah ada dan untuk melengkapi subtema terakhir yaitu Religi dan Kesenian.

Adapun berdasarkan koleksi kebudayaan yang dipamerkan, Museum Nasional memiliki 7 jenis. Yaitu prasejarah, arkeologi, keramik, numismatik-heraldik, sejarah, etnografi dan geografi.

a. Koleksi Prasejarah.

Prasejarah merupakan suatu kurun waktu pada saat manusia belum mengenal tulisan. Di Indonesia, masa prasejarah dimulai sejak keberadaan manusia sekitar 
1,5 juta tahun yang lalu hingga dikenalnya tradisi tulisan pada abad ke-5 Masehi, yaitu ketika ditemukannya prasasti Yupa di Kutai, Kalimantan Timur. Peninggalannya berupa fosil, tulang-belulang manusia dan binatang serta artefak. Berdasarkan bahan dasar pembuatan alat atau teknologinya, secara umum masa prasejarah dibagi menjadi dua zaman, yaitu zaman batu dan zaman logam.

b. Koleksi Arkeologi.

Koleksi arkeologi meliputi bendabenda budaya hasil kegiatan manusia dari masa Hindu Budha dan lebih dikenal dengan sebutan masa Klasik Indonesia. Masa ini berlangsung dari awal abad ke 515 Masehi, dimana berkembang kebudayaan lokal dipengaruhi oleh kebudayaan India. Koleksi arkeologi di Museum Nasional terdiri dari arca dewadewa Hindu, arca Budha, arca perwujudan, arca binatang, perhiasan, peralatan upacara, bagian bangunan, mata uang, prasasti, dan lain-lain. Koleksi-koleksi tersebut terbuat dari emas, perak, perunggu, batu, dan tanah liat yang dibakar. Koleksi Arkeologi sebagian besar berasal dari daerah Jawa Tengah dan Jawa Timur, misalnya temuan emas yang sangat bernilai dari desa Wonoboyo, Jawa Tengah.

c. Koleksi Keramik.

Koleksi keramik kuno di Museum Nasional yang terbanyak berasal dari Cina, dari masa dinasti Han (206 SM-220 M) sampai dengan masa dinasti terakhir, dinasti Qing (1644-1912). Lainnya berasal dari Vietnam (abad ke-14-16 M), Thailand (abad ke-14-16 M), Jepang (abad ke-17-ke $19 \mathrm{M}$ ), Timur Tengah (abad ke 18-ke 19 M) dan Eropa (abad ke 17-ke $19 \mathrm{M}$ ). Koleksi tersebut merupakan data sejarah yang membuktikan adanya hubungan antara Indonesia dengan negara-negara lain di masa lalu, antara lain hubungan perdagangan. Indonesia di masa lalu merupakan penghasil utama rempahrempah untuk komoditi perdagangan. Perdagangan masa lalu dilakukan dengan cara pembayaran uang atau cara tukar- menukar (barter) rempah-rempah dengan keramik yang berasal dari luar negeri.

d. Koleksi Numismatik dan Heraldik.

Koleksi numismatik terdiri dari benda-benda seperti koin, uang kertas dan token yang pernah beredar dan digunakan oleh masyarakat, di samping itu juga terdapat alat cetak uang. Koleksi numismatik Museum Nasional sebagian besar berasal dari masa kerajaan-kerajaan Indonesia kuno, masa kolonial (Belanda, Portugis, Inggris dan Jepang) hingga masa kemerdekaan Indonesia. Selain koleksi numismatik dari dalam negeri, juga terdapat koleksi numismatik yang berasal dari negara-negara di benua Asia, Eropa, Afrika, Amerika dan Australia.

e. Koleksi Sejarah.

Koleksi sejarah Museum Nasional merupakan benda-benda yang mengandung nilai sejarah Indonesia dan benda-benda peninggalan dari masa pendudukan bangsa Eropa di Indonesia, antara abad ke 16 Masehi hingga abad ke 19 Masehi. Koleksi sejarah meliputi benda-benda berupa perabot, meriam, gelas, keramik, lampu hias, gerabah, prasasti dan lain-lain. Benda-benda tersebut umumnya dibuat di Indonesia dan sebagian dibuat di luar negeri, seperti Belanda, Inggris, Jerman, Cina dan Jepang. f. Koleksi Etnografi.

Koleksi etnografi Museum Nasional menyajikan benda-benda atau hasil budaya dari suku-suku bangsa di seluruh Indonesia. Indonesia memiliki lebih dari 300 suku bangsa yang memiliki bahasa dan kebudayaan yang berbeda-beda. Semboyan 'Bhinneka Tunggal Ika' mencerminkan kondisi masyarakat Indonesia yang bersifat majemuk atau multikultural. Benda-benda etnografis itu berupa peralatan hidup yang digunakan oleh suatu suku bangsa baik yang dipakai untuk keperluan upacara maupun seharihari. Koleksi etnografi menunjukkan pengaruh berbagai kebudayaan pada masa Hindu, Islam, dan masa kolonial yang disesuaikan dengan kebudayaan setempat. Penyajian koleksi didasarkan pada 
pengelompokan regional atau geografis yang memberikan gambaran tentang kebudayaan dari tiap-tiap suku bangsa. Untuk menggambarkan keanekaragaman budaya dari Sabang sampai Merauke, ruang pameran etnografi dibagi menjadi tiga ruang, yaitu WIB, WITA, dan WIT.

g. Koleksi Geografi.

Benda budaya yang berkenaan dengan sejarah alam dan lingkungan, baik berupa fosil, batuan, flora dan fauna, peralatan geografi dan sebagainya dapat dimasukkan ke dalam kelompok koleksi Geografi. Koleksi Geografi Museum Nasional saat ini terdiri dari fosil, yaitu fosil toxaster dan amonit yang berumur antara 75-135 juta tahun, koleksi batuan antara lain batuan sedimen, dan metamorf. Berbagai jenis peta antara lain peta tentang aneka budaya bangsa Indonesia, peta dunia pada sekitar abad ke 15-17.

Artinya, keragaman produk di Museum Nasional merupakan salah satu kekayaan koleksi masa silam (HinduBudha) bahkan dikenal sebagai yang terlengkap di Indonesia meskipun hanya sepertiga yang dapat diperlihatkan kepada wisatawan. Produk di Museum Nasional juga dirawat dengan baik dan tersusun rapi di setiap ruangan dengan tata letak produk yang baik sehingga wisatawan tidak dibuat bingung karena dibuat persatu jenis koleksi yang berurutan. Untuk itu pihak Museum Nasional harus lebih dapat meningkatkan kualitas dengan menjaga produk yang sudah ada dan menambah produk melalui penelitian yang dilakukan.

Sementara untuk pelayanan yang diberikan kepada wisatawan yang mengaku betah karena kamera cctv dan petugas keamanan ditempatkan di setiap sudut ruangan guna menjamin keselamatan wisatawan dan koleksi Museum Nasional. Termasuk menyediakan pendingin ruangan (ac), toliet, tempat ibadah, dan tempat istirahat supaya wisatawan merasa nyaman dan istirahat sejenak ketika capai berkeliling. Di samping itu, pihak Museum Nasional menyediakan tim yang siap menjadi pemandu bagi turis asing atau wisatawan domestik dari sekolah atau masyarakat yang sekedar ingin melakukan pre-wedding dan penelitian. Seluruh informasi yang dibutuhkan wisatawan dan masyarakat tersebut diperoleh dengan sambutan yang ramah sehingga menumbuhkan kepercayaan bagi wisatawan dan masyarakat untuk merekomendasikan pelayanan yang baik.

Dari sinilah, pengelola Museum Nasional terus dituntut memaksimalkan kemampuan melalui kegiatan-kegiatan yang selaras dengan tugas dan fungsi. Hal ini sebagai salah satu bentuk penghargaan dan pengakuan akan hasil karya anak bangsa dalam mengabadikan dan menggali nilai-nilai yang sarat kebudayaan. Terlebih informasi yang berasal dari Museum Nasional lebih bersifat kolektif dan dapat memunculkan sikap cinta terhadap museum sejak dini. Hal ini dapat dilihat dari wisatawan yang melakukan kunjungan sebagian besar adalah pelajar baik TK, SD, maupun SLTP. Maka dari itu perlu ditingkatkan lagi dalam bentuk promosi sehingga wisatawan akan terus meningkat di setiap tahun. Terlelbih kelebihan dari Museum Nasional adalah aksesibilitas untuk menuju lokasi tersebut yang tergolong mudah karena berada di kawasan Jakarta Pusat tepatnya sisi barat Monumen Nasional (Monas).

Strategi pengembangan yang dapat dilaksanakan oleh Museum Nasional adalah melalui kemudahan untuk wisatawan. Keunggulan dari produk tersebut dapat dikembangkan dengan sebuah kreativitas, misalnya pembuatan diorama sehingga mudah dimengerti wisatawan yang terkadang malas untuk membaca sebuah sejarah dan kebudayaan. Termasuk segi pelayanan yang menumbuhkan kesan positif sebagai hasil dan tindakan untuk mewujudkan perubahan. Konsep ini pula dapat dikembangkan melalui voice record dalam berbagai bahasa dan digunakan sebagai pemandu bagi wisatawan asing. Jadi, ketika datang wisatawan asing untuk melihat-lihat produk tidak perlu lagi 
menunggu pemandu wisata. Anggaran yang besar ini dapat diperoleh dari bantuan CSR ke perusahaan di dalam maupun luar negeri.

\section{KESIMPULAN DAN SARAN Kesimpulan}

Berdasarkan pembahasan yang telah dilakukan, maka diperoleh kesimpulan sebagai berikut:

1. Produk yang diberikan Museum Nasional terbagi atas 7 jenis yaitu prasejarah, arkeologi, keramik kuno, numismatik-heraldik, sejarah, etnografi, dan geografi.

2. Strategi pengembangan yang dapat dilaksanakan Museum Nasional melalui pembuatan diorama maupun pengadaan voice record. Jika dirasa memberatkan dapat mengajukan melalui CSR.

\section{Saran}

Beberapa saran yang diajukan adalah:

1. Pemerintah (Kementerian Pendidikan dan Kebudayaan dan Dinas di DKI Jakarta) memberikan dukungan supaya mengembangkan aspek yang ada sebagai terobosan terbaru. Jangan sampai ada lagi kejadian koleksi yang hilang.

2. Langkah memperkenalkan budaya bersejarah bisa dimulai dari bangunan museum itu sendiri yang sudah ada sejak abad 17 melalui diorama maupun multimedia lain.

3. Bagi peneliti selanjutnya, penelitian menjadi referensi awal untuk melaksanakan penelitian lanjutan. Nantinya, peneliti selanjutnya dapat mengembangkan strategi Museum Nasional yang sesuai dengan kondisi dan situasi, meliputi atraksi, fasilitas, dan aksesibilitas.

\section{DAFTAR PUSTAKA}

Albrecht, Julia Nina. 2017. Challenges in National-level Tourism Strategy Implementation - a Long - Term Perspective on the New Zealand Tourism Strategy 2015. John Wiley \& Sons: International Journal of Tourism Research.

Company Profile Museum Nasional. 2013.

Gronroos, Christian. 2001. Service Management and Marketing. Lexington Books, $2^{\text {nd }}$. New York: Ad Willey.

Holloway, J. Christopher. Humphreys, Claire. and Davidson, Rob. 2009. The Business of Tourism. Canada: Pearson Education.

Kotler, Philip \& Armstrong, Gary. 2012. Principles of Marketing. New Jersey: Pearson Prentice Hall.

Kotler, Philip. Keller, Lane. and Keller, Kevin. 2009. Marketing Management. Edisi Terjemahan Manajemen Pemasaran, Jilid 2, Edisi Ketigabelas, Jakarta: Indeks.

Kreag, Glen. 2001. The Impacts of Tourism. Sea Grant Minnesota.

Organization, World Tourism, 2008. International Tourism: a Global Perspective. eds. Gee.

Peraturan Pemerintah Nomor 23 Tahun 2005 tentang Pengelolaan Keuangan Badan Layanan Umum.

Undang-Undang Nomor 10 Tahun 2009 tentang Kepariwisataan.

Website

http://www.antaranews.com/berita/ 546349/menunggu-badan-otoritaskelola-candi-borobudur

Ylli, Lorisa. 2016. Increasing Albanian Tourism to Spur Economic Growth. Albania: Academic Journal of Business, Administration, Law and Social Sciences IIPCCL Publishing. Vol. 2 No. 3. 
